\title{
TAXING AND SUBSIDIZING HOUSING INVESTMENT: THE RISE AND FALL OF HOUSING'S FAVORED STATUS
}

\author{
Patric H. Hendershott \\ Michael White
}

Working Paper 7928

http://www.nber.org/papers/w7928

\section{NATIONAL BUREAU OF ECONOMIC RESEARCH 1050 Massachusetts Avenue Cambridge, MA 02138}

October 2000

Earlier versions of this paper were presented at the 2000 AREUEA Midyear Meetings and at the AREUEA International Meeting in Gavle Sweden. We thank James Follain, Don Fullerton, Richard Green, Kenneth Gibb and two anonymous reviewers for helpful comments and/or discussions on various issues. The views expressed are those of the authors and not necessarily those of the National Bureau of Economic Research.

(C) 2000 by Patric H. Hendershott and Michael White. All rights reserved. Short sections of text, not to exceed two paragraphs, may be quoted without explicit permission provided that full credit, including (C) notice, is given to the source. 
Taxing and Subsidizing Housing Investment:

The Rise and Fall of Housing's Favored Status

Patric H. Hendershott and Michael White

NBER Working Paper No. 7928

October 2000

JEL No. H2

\section{$\underline{\text { ABSTRACT }}$}

This paper surveys and interprets a wide body of literature on the taxation and subsidization of investment in owner-occupied and rental housing. Where available, the study considers experiences outside of the United States. Issues addressed include what nonneutral taxation is, how taxation/subsidization has varied relative to this standard over the last thirty years, the impact of subsidies on house prices, housing consumption and tenure, and rationales for preferring one tenure choice over another.

We find a broad increase in housing's favored status during the 1970s, a reversal during the $1980 \mathrm{~s}$, and a further decline in this status during the 1990s. There are two broad components to these shifts. First, there is an endogenous component caused by variations in the inflation rate. Because housing is the tax-favored asset, the higher are nominal returns, the greater is the tax advantage. This is reinforced by tax bracket creep; again, being the tax-favored asset, the higher are tax rates, the greater is the tax advantage. Second, there is an exogenous component, largely reflected in the cutting of tax rates even below what they were in 1970 and the weakening of the mortgage interest deduction in many countries. We attribute this component to the aging of the baby-boomers, which first provided a constituency for more generous treatment of owner-occupied housing, but now is working in the opposite direction.

Patric H. Hendershott

Centre for Property Research

University of Aberdeen

Scotland, UK AB9 1FX

and NBER

p.hendershott@abdn.ac.uk
Michael White

Centre for Property Research

University of Aberdeen

Scotland, UK AB9 1FX

m.white@abdn.ac.uk 
Taxing and Subsidizing Housing Investment: the Rise and Fall of Housing's Favored Status

Patric H. Hendershott and Michael White

Home ownership is tax-favored in all countries because the return from the asset is largely not taxed. Most countries do not tax capital gains on houses, and the (imputed) rents that owners pay themselves rather than landlords are taxed lightly, if at all. Many countries favor home ownership in additional ways: some countries allow mortgage interest to be deducted (the U.S. and many Western European countries, but not the Commonwealth countries); some subsidize the interest rate on new construction (e.g., Sweden); and some have subsidized firsttime homeowners (e.g., Finland, Ireland and Germany currently and Australia and Canada during much of the 1980s).

Many countries also subsidize rental housing. The subsidies include: housing allowances or rent supplements, ${ }^{1}$ below-market interest rates for new construction, including rehabilitation (again Sweden is an example), and, in the U.S. during some periods, relatively low taxation of rental income. Some countries also have rent controls. ${ }^{2}$ This paper deals solely with housing investment or with "supply side" taxes and subsidies. Thus housing allowances and rent controls will not be discussed further. In addition, special subsidies for low-income housing are not considered.

In this paper, we analyze the workings and rationales for these tax advantages and subsidies and discuss how the favorable treatment of housing has varied across countries and

\footnotetext{
${ }^{1}$ While most housing allowances are means tested and go to renters, in some countries (e.g., France and Norway) allowances are also available for owners.

${ }^{2}$ While these are temporarily advantageous to sitting tenants, controls reduce the housing stock, as opposed to the subsidies listed above that tend to expand the stock, and are thus fundamentally detrimental to rental housing.
} 
over time. The paper is divided into five parts. We begin by laying out a framework for the efficient or neutral taxation of structures and applying it to rental housing. We then consider the basic favorable tax treatment of owner-occupied housing. Next, we turn to special subsidies to homeowners, especially first-time owners. Overall, we find a significant increase in the favorable treatment of housing during the 1970s and early 1980 s, but a reversal and then some since. Part of the swing is simply an endogenous response to the rise and fall of inflation.

Next, we take a broader perspective, considering: whether the favorable tax treatment leads to greater housing consumption or higher house prices, what role housing plays in the economy and what positive and negative externalities are associated with owner-occupied housing relative to renter housing. We close by summarizing and speculating on the cause of the exogenous component of the swing in the subsidization of owner-occupied housing over the last quarter century. We offer the aging of the baby boomers as a likely candidate.

\section{The Correct Tax Treatment of Structures}

The correct tax treatment of capital goods is a complex issue. The first question is whether income or consumption is the appropriate tax base. The second question is how to tax capital goods given the choice of tax base. Taxing only consumption suggests full expensing of structure investments, i.e., allowing businesses depreciation deductions equal, in present value terms, to the full value of the investment. Taxing income requires careful measurement of income.

The U.S. has a hybrid system regarding commercial properties, including rental housing, in that present value expensing of roughly half the value of structures investment seems to be the rule. Most European countries also allow tax depreciation write offs for structures (Scholten, 2000) but we know little about the specifics of these. Many European countries 
have also had substantial interest rate subsidies for new construction. For example, Sweden's 1975 program had an initial interest rate of 2.7 percent and only 0.25 percent annual increases. But these interest-rate subsidies have been greatly reduced during the last decade.

What tax depreciation allowances and interest expenses ought to be deductible from rental income and how should capital gains be taxed in a neutral income tax system? If one wishes to subsidize rental housing investment through the tax code, then greater than neutral tax depreciation deductions should be allowed and less than neutral capital gains taxation should be employed. We begin with an analysis of the correct taxation of structures under an income tax. As we shall show, this treatment entails (under most circumstances) no tax depreciation allowances for structures. We then discuss tax depreciation in the U.S., showing that the 1981 and 1986 tax depreciation changes were roughly consistent with equating the present value of tax depreciation allowances to the present value of economic depreciation. This is equivalent to setting the present value of tax depreciations allowances equal to one-half of the value of structures investment.

\section{The Correct Taxation of Real Income ${ }^{3}$}

The general efficiency rule is that taxes should be paid (or loss offsets should be given) on a correct measure of real economic income. The latter takes two forms, capital gains or changes in the value of the asset (V1-Vo) and realized cash flows. For an investor paying $i$ on a debt level equal to $\mathrm{D}$ and earning a net cash flow (rent less operating expenses) of R, pretax (or taxable) income should be, ignoring inflation,

$$
\text { Income }=\mathrm{V} 1-\mathrm{Vo}+\mathrm{R}-\mathrm{iD} \text {. }
$$

\footnotetext{
${ }^{3}$ For a rigorous analysis of capital income taxation, see Auerbach (1983, Section III).
} 
Of course, V1-Vo would be negative if economic depreciation were sufficient (or if a significant reduction in expected future real cash flows occurred). Correcting for inflation at rate inf - that is adjusting the initial price for inflation and allowing the deduction of only real interest payments, we have

$$
\text { Real Income }=\mathrm{V} 1-(1+\mathrm{inf}) \mathrm{Vo}+\mathrm{R}-(\mathrm{i}-\mathrm{inf}) \mathrm{D} \text {. }
$$

This is the same result as equation (1) if the investor uses 100 percent debt financing (replacing D with Vo, the two inflation terms cancel out). This leads us to

Principle 1: If debt is widely employed and nominal interest is deductible, then nominal capital gains should be taxed - equation (1) defines taxable income. But if the inflation premium in interest rates is not deductible (only real interest is), then inflationary gains should not be taxed - equation (2) defines taxable income.

Two aspects of the above income statements are worth further note. First, the appreciation and cash flow components of income are treated similarly - there is full taxation of accruing appreciation gains and current payment of taxes on cash flows. Second, depreciation expense was not mentioned. There was no need to. To the extent that depreciation occurs during the period, V1 is less than it otherwise would have been and thus so is taxable income. As a result, we have

Principle 2: Capital gains taxes should be levied as the gains accrue, not when they are realized, and at the full regular income tax rate. In any event, unless asset prices are falling, no tax depreciation should be allowed.

To obtain a rationale for tax depreciation allowances takes some effort. First, assume that capital gains taxes (or loss offsets if the gains were negative) are paid only upon sale or 
realization. Second, assume that either only real gains are taxed (and only real interest is deductible) or inflation is effectively zero and thus that real gains on average are negative they equal economic depreciation. Tax depreciation allowances are then a means of investors avoiding the delay of tax losses until sale. That is, depreciation allowances permit the investor to realize the tax loss as it accrues - to accelerate it from the sale date to the present (the tax write offs will be "recaptured" on sale, no loss will occur then). Of course, if nominal capital gains tend to exist (appreciation more than outweighs depreciation), then tax depreciation allowances make no sense. They permit investors to take tax deductions when the investors should instead be making tax payments on capital gains. So we have

Principle 3: In nonindexed realization systems - taxes are levied on nominal capital gains when the asset is sold and nominal interest is deductible, a necessary condition for tax depreciation allowances is that the inflation rate be less than the economic depreciation rate (i.e., under three percent for structures). ${ }^{4}$

The above discussion of capital gains taxation, interest deductibility, and tax depreciation is relevant to the taxation of business investments generally, not just housing.

Our final principle is simply that:

Principle 4: All capital goods should be taxed similarly.

Note the potential conflict of this principle with the other three. More specifically, if owneroccupied housing is largely untaxed, as we shall argue below, then other capital should also be lightly taxed.

\footnotetext{
${ }^{4}$ Note that equipment has a far higher rate of depreciation than structures and thus that tax depreciation allowances generally make sense for equipment.
} 
Tax Depreciation in the U.S.

U.S. tax depreciation has always been based on historic cost (price in dollars at date of purchase). However, economic depreciation occurs on replacement cost (the structure price in dollars when depreciation is occurring). Say that a building is viewed as "wearing out $\square$ at $d$ percent a year and that inflation is $p$ percent annually. Economic depreciation per dollar of original investment in the th year after the purchase is $\operatorname{DEPR}_{t}=d(1-d)^{t}(1+p)^{t}$. While depreciation at historic cost decreases over time, the constant rate $d$ being applied to a shrinking base, depreciation at replacement cost tends to increase owing to inflation expanding the base (and indeed does rise if the inflation rate exceeds the depreciation rate -- $p$ $>d$ ). The present value of economic depreciation on a dollar of structure over its economic life is:

$$
\sum_{t=1}^{\infty} \frac{d(1-d)^{t}(1+p)^{t}}{(1+r)^{t}}=\frac{d}{r-p+d}
$$

This present value is independent of inflation under the assumption of a constant real interest rate, $r-p$. With $d$ equal to 0.035 and $r-p$ also equal to 0.035 , the present value of economic depreciation on a dollar of structure is $\$ 0.5$.

In contrast to economic depreciation, the present value of tax depreciation, which is based on historic cost, varies with the inflation rate. Assuming straight-line depreciation over $N$ years and trading (and redepreciation) at the end of the structure $D$ s tax life, the present value is: ${ }^{5}$

$$
\frac{(1+r)^{N}-1}{r N\left[(1+r)^{N}-(1-d)^{N}(1+p)^{N}\right]}
$$

\footnotetext{
${ }^{5}$ The present value is the product of the present value of straight-line depreciation over $\mathrm{N}$ years and an infinite sum of the form $1+x+x^{2}+\ldots$ where $x=(1-d)^{N}(1+p)^{N} /(1+r)^{N}$. The infinite sum equals $1 /(1-x)$.
} 
Setting the value of tax depreciation equal to the above calculated $\$ 0.5$ value of economic depreciation and solving for the N's that are consistent with different $p$ 's, still assuming that both $r-p$ and $d$ equal 0.035 , gives the straight-line historic-cost depreciation tax life consistent with economic depreciation at these p's.

The U.S. seems to have taken the view that tax depreciation should equal economic depreciation at replacement cost. With $d$ and $p$ each equal to 0.035 , economic depreciation per dollar of investment is then just $d$ or 3.5\% a year forever, which is 28.5 -year straight line at historic cost or roughly the current U.S. tax depreciation schedule (allowing trading of properties and rebasing continues the depreciation forever). But this is only because $p$ is low. At the higher inflation rates existing during the late 1960s to mid1980s, a shorter historic tax life would have resulted, and at lower inflation rates a longer tax life would. More specifically, the straight-line historic cost tax lives associated with different expected inflation rates are:

$\begin{array}{llrrlll}\text { inflation rate } & 1.5 & 3 & 8 & 13 & 18 & 30 \\ \text { tax life } & 37 & 30 & 21 & 16.5 & 14.5 & 12\end{array}$

That is, with the current three percent U.S. inflation rate, the tax life would be 30 years, roughly the current 27.5-year current tax life. But with the 13 percent inflation that existed in the U.S. in the early 1980 s, a far shorter tax life of 16.5 years would result, not far from the 15-year tax life adopted in 1981. Follain, Hendershott and Ling (1987) contend that those sharp swings in inflation did, in fact, drive the major changes in tax depreciation lives that occurred during the 1980 s.

Note the stark difference between this result - that depreciation tax lives should be less generous when inflation is low - and the above result that tax depreciation allowances can be appropriate only in very low (negative?) inflation environments. This difference stems from 
viewing taxes as applying to income rather than consumption. Moreover, if owner-occupied housing is broadly tax favored, as we argue in the next section, then according to our fourth principle of correct taxation (all capital goods should be taxed similarly), rental housing and commercial structures should also be tax favored (rapid tax depreciation and light taxation of capital gains could be appropriate). Further, given that the tax subsidy to owner-occupied housing increases with inflation (Hendershott, 1983, and Hendershott and $\mathrm{Hu}, 1983$ ) housing is relatively more tax-favored the higher are nominal yields, then greater tax depreciation (and lower capital gains rates) might be appropriate in higher inflation environments in this second best world.

\section{The Fundamental Tax Advantages of Owner-Occupied Housing ${ }^{6}$}

The fundamental tax advantage to owner-occupied housing is the generally low taxation of the return on the equity invested in the house. Virtually no European country taxes capital gains (France is an exception), and the U.S. excludes the first $\$ 500,000$ in gain. Further, imputed rents are taxed in only about half European countries, and these are taxed at lower effective rates than private market rents are taxed. ${ }^{7}$ For example, Spain and the Netherlands assume rents to be only 2 percent and 1.7 percent, respectively, of value, which, with a 30 percent tax rate, means that annual taxes would be only about a half percent of value. Follain, Ling and McGill (1993) and Bourassa and Hendershott (1994) show that a tax on imputed rent would be progressive for the U.S. and Australia, respectively.

\footnotetext{
${ }^{6}$ This logic of this section draws heavily on Hendershott (1983). See also Laidler (1969) and Woodward and Weicher (1989). Much of the data on European countries in this section comes from McCrone and Stephens (1995) and Scholten (2000).

${ }^{7}$ On the other hand, a number of countries have property taxes (Sweden's is 1.7 percent of value), although often they are collected at the local level (the U.S. has a local one percent tax, on average). A property tax is equivalent to a uniform-rate tax on imputed rents, although if, as is true in the U.S., the tax is deductible against the income tax base, the tax rate is effectively applied at a progressive rate.
} 
The deductibility of mortgage interest expense from the taxable income base is not the fundamental source of the tax subsidy to owner-occupied housing. In fact, if returns to housing were fully taxed, the deductibility of mortgage interest would not be considered a tax advantage, but rather an appropriate business deduction. ${ }^{8}$ Rather, the deductibility of interest is a means of extending the fundamental tax advantage of owner-occupied housing, the low taxation of the return on equity invested in housing, to the numerous less wealthy households who cannot finance their real assets entirely with equity. ${ }^{9}$ Because of this, most countries (but not most of the Commonwealth countries -- Australia, Canada, New Zealand and now the UK) allow a mortgage interest deduction, although many limit it to a fixed amount or allow the deduction to be taken only at a relatively low tax rate.

According to Scholten (2000), Austria, Belgium, Finland, France, Ireland, Luxembourg, Portugal and Spain limit the amount of interest that can be deducted, and Finland, France, Ireland, Italy, Norway and Sweden limit the rate at which the interest is deductible. The UK is an especially interesting case. Beginning in 1983, the UK limited the deductible interest to that on a maximum loan of $£ 30,000$. That limit was never raised, in spite of rising house prices, and the tax rate at which it was deductible has been progressively phased down since 1993 from 25 percent to now zero (Gibb, Munro and Satsangi, 1999). Even in the U.S. deductibility has been limited since 1986 for higher income households (in 1999 for married

\footnotetext{
${ }^{8}$ Moreover, the mortgage deduction is of no value to some households. Consider a household whose marketable wealth equals or exceeds the value of its house and whose best investment alternative is home mortgages of other households (e.g., GNMA securities in the U.S.). The ability to borrow mortgage money, the interest on which is deductible, in order to invest in mortgages, the interest income from which is taxable, is obviously of no value.

${ }^{9}$ The deductibility is thus analogous to safe-harbor leasing in the U. S. in the early 1980s, which allowed firms without taxable income to pay lower effective equipment lease rates. That is, the tax credits and accelerated write-offs available to profitable and slowly or moderately growing firms were effectively made available to nonprofitable and rapidly growing firms. The underlying tax credits and accelerated write-offs, not the leasing, are the fundamental source of the tax advantage. Safe-harbor leasing was adopted in 1981 but then repealed in 1982 (see Feldstein, 1994, p 26 for a discussion).
} 
couples with taxable income over $\$ 124,500$ ). For sufficiently high incomes, a fifth of the mortgage interest is nondeductible. Moreover, sufficiently low income households will take the standard deduction, effectively foregoing the mortgage deduction totally (Ling and McGill, 1998).

The amount of debt used or the LTV is quite sensitive to the deductibility of interest. Capozza, Green and Hendershott (1996) estimate the decline in mortgage debt that would occur in response to removal of the mortgage interest deduction in the U.S. in two ways. ${ }^{10}$ First, they lower individual household mortgage debt data from the 1989 Survey of Consumer Finance by the amount of household liquid assets. The result is a nearly forty percent decline in mortgage debt. The decline is skewed toward higher income households. Second, because Australia has not had a mortgage interest deduction, CG\&H estimate demand equations for households in the U.S. that are comparable to those estimated for Australia by Bourassa and Hendershott (1994) and contrast the results. The predicted U.S. LTVs for ages 25-29, 40-44, and 55-59 (with Australia in parentheses) are $0.56(0.42), 0.34(0.12)$ and $0.16(0.01)$. Again, the result is about a forty percent lower LTV where interest is not deductible (Australia).

Follain and Melamed (1998) estimate the impact of removing the mortgage interest deduction in the U.S. on both the quantity of debt and Treasury tax revenue. Their simulation model of the demand for mortgage debt, based on the Follain and Dunsky (1997) estimates from an analysis of nearly 5000 households in 1983 and 1989, predicts that removing the deduction would reduce mortgage debt by 40 percent and that the decline would be significantly more at higher income levels $¥ ¥$ only 18 percent at the $\$ 22,500$ level, but 54 percent at $\$ 55,000$ and 69 percent at $\$ 110,000$, results similar to Capozza, Green and

\footnotetext{
${ }^{10}$ They also analyze the likely impacts of fundamental tax reforms on debt usage and speculate on the impacts of all these on house prices.
} 
Hendershott. With lower mortgage debt, especially for those with higher income, Follain and Melamed estimate the pick up in tax revenue from removing the deduction to be only a quarter to a third of what it would be without any pay down in mortgage debt. That is, the extension of the fundamental tax advantage of owner-occupied housing to the less wealthy is not nearly as costly as official government calculations that do not allow for an obvious behavioral response of households. ${ }^{11}$

Whether houses are financed by equity or debt, the magnitude of the tax advantage is directly related to both the household's marginal tax bracket and the level of nominal pretax returns in the economy. The higher the tax bracket or the level of returns, the more valuable is the nontaxation of the returns. Because the tax advantage increases with the marginal tax bracket of the household, the demand for owner-occupied housing is greater the higher the tax bracket of the household. The tax advantage is clearly less in countries with flat (low) tax rate schedules. Shifting to a lower tax rate income tax structure is the primary available avenue through which most countries can reduce the subsidy to owner-occupied housing.

The U.S. and most European countries have made this switch since 1980. The U.S. cut its maximum Federal tax rate from 70 percent to only 31 percent in 1986, although since then it has risen to above 40 percent when phaseouts are taken into account (the rate can approach 50 percent in some areas owing to state and sometimes local income taxes). Sweden cut its rate from the high 70 s in the early 1980 s to 50 percent in 1991, although it to has risen back to 60 percent. Somewhat similarly, the maximum UK tax rate was cut from 83 percent in 1979 to 40 percent in 1988, where it remains today. Virtually all European countries have simplified their tax systems (gone to fewer tax brackets) and lowered their marginal tax rates.

\footnotetext{
${ }^{11}$ For a general discussion of behavioral responses to tax changes in the context of the Tax Reform Act of 1986, see Auerbach and Slemrod (1997).
} 


\section{Other Ownership Subsidies}

Young households with limited wealth for a downpayment have sometimes been the explicit target of government policy. Because the wealth constraint is especially binding during periods of high inflation and nominal interest rates when real mortgage payments are initially very high relative to income (the mortgage tilt problem) and thus household need to make above normal downpayments in order to have affordable monthly mortgage payments, assistance is most needed during these periods. Four examples of special government assistance efforts are the First Home Owners Scheme (FHOS) adopted in Australia in 1983 and currently available in Ireland, ${ }^{12}$ the Registered Home Ownership Savings Plan (RHOSP) adopted in Canada in 1974, the Swedish interest rate subsidies for new construction initiated in 1975 (the other Scandinavian countries, France and Austria also have interest rate subsidies for new construction) $)^{13}$ and the high LTV, long-term Federal Housing Authority loans established in the U.S. in 1934.

These efforts are described in turn. But first, we discuss evidence on the credit constraints and their impact on homeownership. Three influential papers were published in 1989 . Linneman and Wachter (1989) and Zorn (1989) provided the evidence that both downpayment (no loans are available with less than, say, five percent down) and income (no loans with payments greater than, say 28 percent of household income) constraints reduced homeownership. Jones (1989) provided evidence on the impact of the wealth or downpayment constraint only.

\footnotetext{
${ }^{12}$ Ireland currently has roughly a 5 percent downpayment subsidy for first time homebuyers.

${ }^{13}$ Germany has a particularly novel scheme, where it allows the deduction of $38 \%$ of the structure value and half of the land value during the first eight years of ownership (McCrone and Stephens, 1995). Because this is a once in a lifetime allowance, it is effectively a first-time homebuyer subsidy.
} 
Haurin, Hendershott, and Wachter (HHW, 1997) extended the earlier analyses by treating household income and wealth as endogenous variables (households who want to become owners work longer hours and save more) and by allowing households to minimize the impact of these two constraints through choice of mortgage type and loan-to-value ratio. On the latter, see Hendershott, LaFayette and Haurin (1997). Although allowing households to choose mortgage type and LTV results in the constraints binding on fewer households, the estimated impact of constraints on ownership is increased. ${ }^{14}$ If a young household's probability of being an owner in the absence of being credit constrained is one-half, HHW estimate that being constrained reduces the probability to only one-sixth.

\section{The Australian FHOS}

When introduced in 1983, the FHOS provided first-time owners with nearly $\$ 6000$ in present value of benefits if their taxable income were less than 130 percent of average male weekly earnings and the household head had two or more dependents. Without dependents, the benefit still exceeded $\$ 4000$. The $\$ 6000$ was roughly eight percent of the mean value of a three-bedroom house. Borrowers could take the subsidy as an up-front lump sum, a cash flow subsidy declining over five years, or a combination. That is, the subsidy allowed households to relax whichever of the downpayment or income constraint was the most binding. Fivesixths of households choose the lump sum only.

The value of the subsidy was eroded by inflation during the remainder of the 1980 s and the program was eliminated in 1990. Bourassa, et al (1994) examine data from the Australian National Longitudinal Survey of Youth. They conclude that the program caused the

\footnotetext{
${ }^{14}$ Follain and Dunsky (1997) examine the demand for mortgage debt, but their emphasis is on the responsiveness of mortgage demand to the deductibility of interest, rather than to binding credit constraints.
} 
ownership rate for 21-25 year olds to rise from 28.5 to 37.1 percent. Put another way, it accelerated the time to first ownership by two years.

\section{The Canadian RHOSP}

In 1974 Canada introduced the RHOSP, which allowed a dollar-for-dollar deduction for savings targeted for a downpayment. Further, interest on these accounts accumulated tax free. The annual deduction was limited to $\$ 1000$ (\$2000 for married couples), with a lifetime limit of $\$ 10,000(\$ 20,000)$. Engelhardt $(1997$, p 227) computes that a married couple contributing the maximum amount for three years would have accumulated twice as large a downpayment as without the tax subsidy or another three to five percent of the value of an average house. Given that first-time borrowers generally purchase below average valued houses, this likely understates the potential of the subsidy to finesse the downpayment constraint. ${ }^{15}$ The value of the subsidy was eroded by inflation in the late 1970 s and early 1980s and the program was discontinued in 1985 as part of tax reform legislation.

Using individual household data from the Canadian Family Expenditure Surveys, Engelhardt finds that young (under age 45) households in higher income tax brackets were more likely to participate in the program than were households in lower income tax brackets and that young renting households generally were more likely to transition to homeownership the higher their income tax rate. Most important, the tax rate impact was greater when the RHOSP existed (1982 and 1984) than when it did not (1986). And this result is after inflation had significantly reduced the value of the subsidy. Engelhardt concludes that the program

\footnotetext{
${ }^{15}$ On the other hand, the assumed 44 percent tax rate of the household is greater than the sample mean of 36 percent and the three years accumulating the downpayment is about double the sample mean of about 1.5).
} 
raised the annual rate of transition to homeownership by 20 percent. While the program certainly increased transition, the basis of this calculation is not totally clear.

Beginning in 1998, the U.S. has allowed tax-free, penalty-free withdrawals from IRAs for use as a downpayment for first-time homeowners. This plan appears strikingly similar to the Canadian plan, with the withdrawal limited to $\$ 10,000$. There are, however, reasons to believe that the plan will have decidedly less impact on homeownership than the Canadian plan. First, tax-free status on the IRA can be achieved without using the funds for the purchase of a house. Second, the funds have to be in the account for five years for the withdrawal to be tax-free. In Engelhardt's sample the mean investment period in the tax-free accounts for first-time purchasers was only 1.5 years, even though contributions for up to five years were tax free. The five-year restriction would therefore bind on most potential firsttime buyers, causing their withdrawals to be taxable.

\section{Sweden's Construction Loan Subsidies}

Sweden has subsidized new construction since $1975 .{ }^{16}$ Loans of 95 percent of Dapproved building costs" were given to purchasers of new houses or major renovations that complied with government minimum and maximum standards (roughly 85 percent of new units qualified). The loans had an initial interest rate of 5.5 percent, which rose by 0.5 percent per year (the subsidy was intended to address the mortgage tilt problem during the $1975-85$ inflationary period). ${ }^{17}$ During the $1981-92$ period, market interest rates varied between 12

\footnotetext{
16 This paragraph is based on Englund, Hendershott and Turner (1995) and Berger et al (2000). Sweden taxed imputed rent, although rent was estimated to be only one percent for most households (it jumped to about four percent for quite large houses), until Sweden's recent switch to a property tax.

${ }^{17}$ For rental housing, the initial rate started at $2.7 \%$ and rose by only $0.25 \%$ annually. The shallower interest-rate subsidy for owner than renter housing was an attempt to counterbalance the nontaxation of the returns from owner-occupied housing so as to treat the two tenures neutrally.
} 
and 16 percent. The favorable financing transferred with the house when it was sold. Under plausible assumptions, the present value of the subsidy was 15 to 25 percent of house value.

Berger et. al. (2000) estimate that the subside value was fully capitalized into house prices, providing substantial value to the original purchaser. Legislated increases in the initial interest rate and declines in nominal market interest rates in the middle 1990s have substantially eroded this subsidy as well as other interest rate subsidies in Europe. The result, of course, was a reversal of the earlier rise in real house prices.

\section{The U.S. Federal Housing Authority}

Rather than subsidizing first-time homebuyers with grants or substantial below-market interest rates, many countries have established government-sponsored lenders to make or insure higher loan-to-value ratio loans to alleviate the downpayment constraint problem. These programs need not be subsidized, although often a shallow subsidy is involved. The U.S. FHA Mutual Mortgage Insurance Fund, which was established in 1934 to make high LTV, long-term fully amortizing loans, is a prime example.

This insurance was designed to be priced fairly, but has periodically been under or over priced. When house price inflation accelerated during the 1970s, mortgage default rates declined and the FHA insurance fund made substantial money on books of business insured. Ex post, borrowers were overcharged. When house price inflation plummeted in wide regions of the U.S. during the 1980s, defaults surged and FHA took large losses. Borrowers were effectively undercharged. The losses were in fact so large that the FHA Fund, while still solvent in 1989, it was not deemed to be actuarially sound (Hendershott and Waddell, 1992). In response, Congress passed legislation to substantially raise insurance fees (and to introduce risk-based pricing - higher insurance fees for higher LTV loans). House prices have 
performed much better and one can reasonably conclude that, again, ex post, 1990s borrowers have been overcharged. ${ }^{18}$ Not surprisingly, insurance premia are now being lowered.

\section{Broader Issues}

Here, we consider three topics that are relevant to the optimal taxation/subsidization of housing: the impact of the subsidies on housing consumption and house prices, the role of housing in the economy, and the positive and/or negative externalities provided by owneroccupied housing relative to rental housing.

\section{Housing Consumption or Price?}

The favorable treatment of owner-occupied housing results in increased demand. The increased demand can lead to increased housing consumption and homeownership, but this need not be the case owing to capitalization effects. Berger et.al. (2000) provide evidence that the Swedish interest rate subsidies were fully capitalized into house prices (the original purchaser of the subsidized new construction captured all the subsidy). Capozza, Green and Hendershott (1999) argue more generally that all owner-occupied housing subsidies are fully capitalized into urban land prices. That is, declines in real after-tax interest rates, including those caused by the introduction of interest rate subsidies, would raise land prices, not housing consumption and the homeownership rate. Of course, their analysis would not hold in rural areas where additional land can be readily developed. ${ }^{19}$

\footnotetext{
${ }_{18}$ The differential behavior of books of business originated during the 1980s and 1990s depended heavily on refinancing and the regular and streamline refinancing policies of FHA (Brickman and Hendershott, 2000).

${ }^{19}$ For the more traditional view that quantity demanded would be reduced, see Bruce and Holtz-Eaton (1999). For early arguments that the U.S. over consumes housing, see Hendershott and $\mathrm{Hu}$ (1980), Hendershott (1987) and Mills (1987).
} 
The removal of subsidies would have the opposite effect in this framework. House prices, not housing consumption and homeownership, would decline. And the cuts in marginal tax rates that would occur in the movement to a flat tax (lower tax rate schedule, but fewer deductions) would also lower house/land prices, rather than housing consumption and ownership.

\section{Housing and the Economy}

Residential investment is a significant component of Gross Domestic Product (GDP), generally ranging from four to eight percent of GDP in developed countries. Moreover, it is the most volatile component of investment, and total investment is far more volatile than consumption (seven times more volatile in the U.S.). With this greater volatility, we might expect that housing has a disproportionately large role in the business cycle.

Green (1997) examined the role of residential and nonresidential investment in the U.S. economy over the 1959-92 period. More specifically, he tested (with quarterly data) whether these investment components caused movements in GDP or whether GDP caused movements in the investment components. He found that residential investment caused movement in GDP, not the reverse, but that GDP caused movement in nonresidential investment, rather than the other way around. Thus actions that would temporarily depress residential investment could easily trigger a recession and those that would stimulate residential investment could unleash an inflationary boom. This suggests that one should avoid severe short-run changes in housing subsidies.

We have performed somewhat analogous tests for the UK (see the Appendix) using quarterly data from 1968 to 1998 . We test whether GDP causes house prices or the reverse. Our results are consistent with Green's in that the causation runs from house prices to GDP but not the reverse. 
Attanasio and Weber (1994) have also examined the interaction between income expectations, financial deregulation and real house prices. They suggest that higher real permanent income causes higher real house prices that in turn increase real GDP via increased real consumer expenditures. Berg (1994) obtained similar results for the Nordic countries. Financial deregulation and tax changes affected house prices in the late 1980s, which in turn altered consumption and thus GDP. Skinner (1994) surveys U.S. studies, arguing that the life cycle model suggests a significant temporary increase in consumption in response to increases in real house prices. Empirically, Skinner finds the evidence to be mixed.

\section{Which Tenure Should Be Subsidized?}

A large body of literature has extolled the benefits of home ownership in the abstract. The positive externalities presumed to be associated with ownership include that owners better maintain their housing and neighborhoods, are better citizens in that they are more likely to support their local schools and to vote, and are superior at childraising. We have recently begun to see econometric tests of these presumptions. The tests are complicated because we need to hold constant household characteristics in order to compute the ceteris paribus impact of ownership. Researchers do this by adjusting for differences in income, race, gender and educational background of parents. Kane (1994) finds that blacks are more likely to graduate from high school if their parents are homeowners and that both white and black high school graduates are more likely to enroll in college if their parents are owners. Similarly, Green and White (1997) find that children of homeowners stay in school longer than children of renters. They also report that daughters of homeowners are less likely to have children as teenagers than are daughters of renters. DiPasquale and Glaeser (1999) deduce that owners are more civic-minded. 
While this evidence in support of the formerly just-presumed benefits of home ownership provides a rationale for subsidizing it, whether homeownership really supplies these benefits or simply proxies for household characteristics that researchers have not been able to hold constant, is spite of heroic efforts, is uncertain. For example, some studies are unable to hold parental characteristics or location constant. Moreover, controlling for numerous characteristics is not sufficient; selection bias must be addressed directly.

However, a recent study of Haurin, Parcell and Haurin (2000) on the effects of home ownership on a child's cognitive and behavioral outcomes makes it even more difficult to reject the hypothesis of no impact of home ownership because they are able to control for so many factors. Their data set, the National Longitudinal Survey of Youth augmented by the NLSY-Child Data, consists of more than 1,000 children, ages five to eight in 1988, who also were surveyed in 1990, 1992, and 1994. The child data are matched with extensive social, demographic, and economic data on parents, this information first collected in 1979 and updated annually. Instrumental variable techniques are used to control for a myriad of factors.

They use a random effects econometric model to estimate the impact of home ownership on the quality of the home environment and the impact of home environment and home ownership on child outcomes and find substantial positive effects of home ownership on the home environment. Further both increased quality of home environment and home ownership directly have a statistically significant and positive effect on increasing child cognition and reducing child behavior problems. The math and reading achievements of children of owners are up nine and seven percent respectively, and child behavioural problems are down three percent, all of these being statistically different from zero. Further, the longer a parent owns a home, the greater is their children's cognition and the lower are behavior problems. 
On the other hand, recent work by A.J. Oswald (1996) suggests that a major negative externality may be associated with ownership: more specifically higher unemployment seems to accompany/be-caused-by greater homeownership. Oswald's argument is that homeowners are less mobile than private renters and thus are less willing to move to jobs when they become unemployed. Oswald emphasizes a number of "indirect" effects. Areas with high home ownership rates have greater planning laws and restrictions on land development, discouraging business start-ups, and have greater congestion owing to owners commuting further than renters, increasing the cost of having a job. Of course the primary reason that owners are less mobile is that they have, after all, chosen to be owners in part because their annualized user cost is lower owing to the ability to spread one time transactions costs of buying and selling over a longer period.

Housing economists might refer directly to the causes of unemployment increases, rising interest rates and falling real incomes, both of which lower house prices. Lower prices in turn prevent owners who had made low downpayments from remaining owners if they were to move (Caplin, Freeman and Tracy, 1997, and Archer, Ling and McGill, 1996). Instead, (employed) households respond by increasing their saving to rebuild their equity (Engelhardt, 1996). Rising interest rates also reduce mobility of households with nonassumable mortgages because they are unwilling to give up now below-market interest rates on long-term fixed-rate loans (Hendershott and Hu, 1982, and Quigley, 1987).

Oswald provides an impressive array of data indicating a positive, and large, relationship between homeownership and unemployment: a ten percentage point increase in ownership leads to a two percentage point increase in unemployment. The data supporting this finding are both cross-sectional for countries (in both 1960 and 1990) and for regions within countries (European regions and U.S. states) and time series for countries (changes between 1960 and 1990) and for U.S. states (changes between 1970 and 1990). In effect, Oswald sees 
the rise in homeownership in Europe since 1960 as explaining the rise in unemployment, and current differences in homeownership rates across countries are seen to explain much of current differences in unemployment rates.

Green and Hendershott (2000) examine the U.S. states data in more detail, considering how the homeownership-unemployment relationship varies by household type and age. These computations are based on 5 in 100 samples of the 1970 and 1990 U.S. Censuses. As expected the relationship is weaker for household heads than for the entire labor force, household heads being less likely than others to be deterred from moving in response to unemployment by the fact that they are homeowners. Also as expected the relationship is weaker for young (under age 35) and old (over age 65) households. The young have had less time to get attached to their geographic locale and have less wealth to carry them through periods of unemployment, and thus are less deterred from moving by ownership, while even old renters have enough wealth to allow them to not relocate when they become unemployed.

To summarize, the Green and Hendershott analysis supports Oswald's hypothesis. His result does not, for example, seem to be the result of changes in the age structure of the population. This is certainly an area for further research, particularly with microeconomic data.

\section{Summary}

Worldwide, the fundamental subsidy to owner-occupied housing is that the returns -imputed rents and capital gains -- are very lightly taxed. In countries allowing the home mortgage interest deduction, the tax advantage is extended to lower wealth households that cannot all-equity finance their houses. Many countries recognize the basic "fairness" in this extension, although most limit the deductibility for higher income (and maybe wealth) households by setting a maximum on the tax rate at which the interest can be deducted, on the 
total allowed deduction or on both. Given the light taxation of owner-occupied housing, the only available way to limit the subsidy is to adopt a flatter tax rate schedule with fewer deductions. And given this favorable treatment, efficient allocation of capital requires subsidies to other forms of investment in structures (tax depreciation allowances and favorable capital gains treatment), subsidies that would otherwise be inappropriate.

A number of countries have provided additional subsidies to owners via below-market interest rates, one-time upfront grants, or regular cash payments (housing allowances). Such subsidies, which are sometimes targeted to first-time buyers or to new construction, were generally expanded in the late 1970 s and early 1980 s but have been substantially reduced in Western Europe and elsewhere during the last decade. A major problem for all owner subsidies to households in urban areas is the possibility that the subsidies are just capitalized into higher house (land) prices. This requires either a broad subsidy to all owners or a subsidy tied to specific houses (the Swedish new construction interest rate subsidy or below market nonassumable mortgages); first-time owner subsidies that are not tied to specific houses should not be expected to be capitalized. To the extent that the subsidy is not capitalized and thus leads to greater homeownership in a country, the work of Oswald suggests that higher unemployment will result. At a minimum, both of these results argue for limiting ownership subsidies.

The most widespread rental subsidy is housing allowances targeted to lower-income households (often especially those containing children or pensioners). Some countries have subsidized new construction via below-market interest rates or through substantial tax depreciation allowances. Here, too, the subsidization of new construction has waned during the last decade. And the targeting of housing allowances has probably increased.

What explains the large swings during the last quarter century in the favorable treatment of homeownership and what is the future likely to hold? A substantial part of the swing was 
an endogenous one caused by the rise and fall of inflation. When inflation rises so do nominal rates of return. Owner-occupied housing, being the untaxed capital good, benefits. And in the absence of indexation, rising inflation increases marginal tax rates, further increasing the nontaxed asset's advantage. Of course, a fall in inflation reverses this increased advantage. But the rise in inflation was also accompanied by specific favorable actions, e.g., the Australian and Canadian first-time ownership subsidies and the massive Swedish new construction subsidies. These were all reversed during the 1980s and 1990s. Moveover, the reversals generally more than offset the 1970s increases in favorable treatment. We refer specifically to the sharp declines in marginal tax rates in most of North America and Europe, as well as the general erosion of the mortgage interest deduction.

In the U.S., substantial concern has been expressed regarding the decline in home ownership during the 1980s, especially among the young. Follain, Hendershott and Ling (1992, pp 262-63) note that the ownership rate for married couples under age 35 fell by over seven percentage points between 1980 and 1990. They also argue that the decline was largely a response to the demise of inflation and tax rate cuts, not to reduced affordability. Green (1996) confirms this in his analyses of state data. His estimates of price/income and payment/income ratios of potential first-time owners fell in 42 and 47 states, respectively. In contrast to this general rise in affordability, ex ante user costs rose in 49 states.

The exogenous component of the swing toward favorable treatment of homeownership and then back correlates roughly with the shift of the baby-boomer cohort into, and out of, its years of increasing homeownership, ages 25 to 40 (in 1990 the U.S. rate rose from 18 percent for households under age 25 to 69 percent for households 35 to 44). The boomer cohort was borne between about 1947 and 1962, so in the early 1970s it began turning age 25 . By the late 1980s, the youngest of the boomers were reaching age 30 and the oldest had already passed through the years of rising ownership. By 2000 virtually all boomers are in their 40s 
and 50s. As this cohort was becoming owners, they (and their parents!) were a major political force for subsidizing homeownership. By the late 1980s and 1990s, their concerns were shifting in other directions, such as shoring up the retirement pensions of their parents (and themselves in the future). From this perspective, a return to the earlier substantial subsidies for homeownership seems unlikely. 


\section{References}

Archer, Wayne R., David C. Ling, and Gary A. McGill. 1996. The Effect of Income and Collateral Constraints on Residential Mortgage Terminations. Regional Science and Urban Economics. 26: 235-261.

Attanasio, O.P. and G. Weber. 1994. The UK Consumption Boom of the Late 1980s: Aggregate Implications of Macroeconomic Evidence. Economic Journal 104: 1269-1302.

Auerbach, Alan J. 1983. Taxation, Corporate Financial Policy and the Cost of Capital. Journal of Economic Literature. 21: 905-940.

Auerbach, Alan J. and Joel Slemrod. 1997. The Economic Effects of the Tax Reform Act of 1986. Journal of Economic Literature. 35:589-632.

Berg, L. 1994. Household Savings and Debts: The Experience of the Nordic Countries. Oxfor Review of Economic Policy, 10: 42-53.

Berger, Tommy, Peter Englund, Patric H. Hendershott, and Bengt Turner. 2000. Another Look at the Capitalization of Interest Subsidies: Evidence from Sweden. Journal of Money, Credit and Banking. 32:.

Bourassa, Stephen.C., Donald R. Haurin, R. Jean Haurin and Patric H. Hendershott. 1994. Independent Living and Home Ownership: An Analysis of Australian Youth. The Australian Economic Review, 29-44.

Bourassa, Stephen C. and Patric H. Hendershott. 1994. On the Equity Effects of Taxing Imputed Rent: Evidence from Australia. Housing Policy Debate. 5: 73-95.

Brickman, David and Patric H. Hendershott. 2000. Mortgage Refinancing, Adverse Selection, and FHA's Streamline Program. Journal of Real Estate Economics and Finance, 20:.

Bruce, Donald and Douglas Holtz-Eakin. 1999 Fundamental Tax Reform and Residential Housing. Journal of Housing Economics. 8: 249-71.

Caplin, Andrew C., Charles Freeman, and Joseph Tracy. 1997. Collateral Damage: Financing Constraints and Regional Recessions, Journal of Money, Credit and Banking. 29: 496-516.

Capozza, Dennis, Richard Green, and Patric H. Hendershott. 1996. Taxes, Mortgage Borrowing, and Residential Land Prices. In Henry J. Aaron and William G. Gale (eds) Economic Effects of Fundamental Tax Reform. Brookings Institution Press, 171-210.

Capozza, Dennis, Richard Green, and Patric H. Hendershott. 1999. Tax Reform and House Prices: Large or Small Effect. NTA Proceedings of the $91^{\text {st }}$ Annual Conference 19-24.

Dipasquale, Denise and Edward L. Glaeser. 1999. Incentives and Social Capital: Are Homeowners Better Citizens? Journal of Urban Economics. 45: 354-84.

Engelhardt, Gary V. 1997. Do Targeted Savings Incentives for Homeownership Work? Journal of Housing Research. 8: 225-248.

Engelhardt, Gary V. 1996. House Prices and Home Owner Saving Behavior. Regional Science \& Urban Economics 26:313-336. 
Englund, Peter, Patric H. Hendershott, and Bengt Turner. 1995. The Tax Reform and the Housing Market. Swedish Economic Policy Review. 2: 319-356.

Feldstein, Martin. 1994. American Economic Policy in the 1980s: A Personal View. In Martin Feldstein (ed) American Economic Policy in the 1980s. The University of Chicago Press, 1-79.

Follain, James R. and Robert M. Dunsky. 1997. The Demand for Mortgage Debt and the Income Tax. Journal of Housing Research. 8: 155-199.

Follain, James R., Patric H. Hendershott and David C. Ling. 1987. Understanding the Real Estate Provisions of the Tax Act: Their Motivation and Impact. National Tax Journal. 40: 363-372.

Follain, James R., Patric H. Hendershott and David C. Ling. 1992. Real Estate Markets Since 1980: What Role Have Tax Changes Played? National Tax Journal. 45:253-266.

Follain, James R., David C. Ling and Gary A. McGill. 1993. The Preferential Income Tax Treatment of Owner-Occupied Housing: Who Really Benefits? Housing Policy Debate. 4: 1-24.

Follain, James R. and Lisa S. Melamed. 1998. The False Messiah of Tax Policy: What Elimination of the Home Mortgage Interest Deduction Promises and a Careful Look at What It Delivers. Journal of Housing Research. 9: 179-199.

Gibb, Kenneth., M. Munro and M. Satsangi. 1999. Housing Finance in the UK, MacMillan Press LTD.

Green, Richard K. 1997. Follow the Leader: How Changes in Residential and Nonresidential Investment Predict Changes in GDP. Real Estate Economics. 25: 253-270.

Green, Richard K. 1996. Should the Stagnant Homeownership Rate be a Source of Concern? Regional Science \& Urban Economics. 26:337-368.

Green, Richard K. and Michelle .J. White. 1997. Measuring the Benefits of Homeowning: Effects on Children. Journal of Urban Economics. 41: 441-461.

Green, Richard K. and Patric H. Hendershott. 2000. Homeownership and Unemployment in the U.S. Urban Studies.

Haurin, Donald R., Toby L. Parcel, and R. Jean Haurin. 2000. The Impact of Home Ownership on Child Outcomes. Working Paper.

Haurin, Donald R., Patric H. Hendershott and Susan M. Wachter. 1997 Borrowing Constraints and the Tenure Choice of Young Households. Journal of Housing Research. 8: 137-154.

Hendershott, Patric H. 1983. Government Policy and the Allocation of Capital Between Residential and Industrial Uses. Financial Analysts Journal, The Financial Analysts Federation. 3-8.

Hendershott, Patric H. 1987. Government Policy and the Allocation of Capital Between Residential and Industrial Uses. In Martin Feldstein (ed) The Effects of Taxation on Capital Formation.University of Chicago Press, 259-290.

Hendershott, Patric H. and Sheng Hu. 1982. Accelerating Inflation, Nonassumable Fixed Rate Mortgages, and Consumer Choice and Welfare, Public Finance Quarterly, 158-184. 
Hendershott, Patric H. and Sheng Hu. 1983. The Allocation of Capital Between Residential and Nonresidential Uses: Taxes, Inflation, and Credit Market Constraints. Journal of Finance.38: 795-812.

Hendershott, Patric H. and Sheng Hu. 1980. Government-Induced Biases in the Allocation of the Stock of Fixed Capital in the United States, in George von Furstenberg (ed.) Capital, Efficiency and Growth. Ballinger Publishing Co., 323-360.

Hendershott, Patric H., William LaFayette and Donald R. Haurin. 1997. Debt Usage and Mortgage Choice: The FHA-Conventional Decision. Journal of Urban Economics. 41: 202-217.

Hendershott, Patric H. and James Waddell. 1992. Changing Fortunes of FHA's Mutual Mortgage Insurance Fund and the Legislative Response. Journal of Real Estate Economics and Finance, 5: 119-132.

Jones, Laurence. 1989. Current Wealth and Tenure Choice. 1989. AREUEA Journal. 17:7-40.

Kane, T.J. 1994. College Entry by Blacks since 1970: The Role of College Costs, Family Background, and the Returns to Education, Journal of Political Economy. 102: 878-907.

Laidler, David. 1969. Income Tax Incentives for Owner-Occupied Housing, in The Taxation of Income from Capital, Arnold. C. Harberger and Martin J. Bailey (eds.). Brookings Institution. 50-76.

Ling, David C. and Gary A. McGill. 1998. Evidence on the Demand for Mortgage Debt by Owner Occupiers. Journal of Urban Economics. 44: 391-414.

Linneman, Peter, and Susan M. Wachter. 1989. The Impacts of Borrowing Constraints on Homeownership. AREUEA Journal.17: 389-402.

McCrone, G and M. Stephens. 1995. Housing Policy in Britain and Europe. UCL Press Limited.

Mills, Edwin. 1987. Has the United States Overinvested in Housing? AREUEA Journal. 15:601-616.

Oswald, Arnold J. 1996. A Conjecture on an Explanation for High Unemployment in the Industrialized Nations: Part I. University of Warrick working paper No.475.

Quigley, John M. 1987. Interest Rate Variations, Mortgage Prepayments and Household Mobility. Review of Econoomics and Statistics, 49: 636-643.

Scholten, Ulrich. 2000. The Euro and Owner-Occupancy Rates in Europe. Working Paper.

Skinner, Jonathan. 1994. Housing and Saving in the United States, in Housing Markets in the United States and Japan, Yukio Noguchi and James M. Poterba (eds.). The University of Chicago Press. 191-213.

Woodword, Susan and John Weicher. 1989. Goring the Wrong Ox: A Defense of the Mortgage Interest Deduction. National Tax Journal. 42: 301-31.

Zorn, Peter. 1989. Mobility-Tenure Decisions and Financial Credit: Do Mortgage Qualification Requirements Constrain Homeownership? AREUEA Journal. 17: 1-16. 


\section{Appendix: Granger Causality Tests for UK House Prices}

Analysing UK quarterly data covering the period 1968 to 1998 and employing the methodology developed by Granger (1969) it is possible to test whether GDP Granger-causes house prices and viceversa. ${ }^{20}$ A simple parsimonious approach is employed and the variables used are real GDP and real house prices (as an index). In order to test for Granger causality, it is necessary to test whether these variables form a cointegrating relationship which itself requires a preliminary test to determine the orders of integration of the series. Unit root tests were therefore performed and suggested that both of these variables were I(1), stationary in first differences. The test results are presented in table A1 below.

\section{Table A1 Dickey-Fuller Unit Root test Results}

\begin{tabular}{|l|l|}
\hline GDP & $-4.139^{* * *}$ \\
\hline House Prices & $-3.906^{* * *}$ \\
\hline
\end{tabular}

*** indicates significance at the $1 \%$ level.

The next step is to test for co-integration. Johansen's (1991) methodology was used to test for the presence of a co-integrating vector. These results are reported in table A2 where the null hypothesis of no co-integration could be rejected at the 5\% level. One co-integrating equating was found to exist.

Table A2 Johansen Cointegration Test

\begin{tabular}{|l|l|l|l|l|}
\hline Eigenvalue & Likelihood Ratio & $\begin{array}{c}5 \% \text { Critical } \\
\text { Value }\end{array}$ & $\begin{array}{c}1 \% \text { Critical } \\
\text { Value }\end{array}$ & $\begin{array}{c}\text { Hypothesised } \\
\text { Number of } \\
\text { Cointegrating } \\
\text { Equations }\end{array}$ \\
\hline 0.151 & 20.574 & 18.17 & 23.46 & None** \\
\hline 0.009 & 1.101 & 3.74 & 6.40 & At Most 1 \\
\hline & & & & \\
\hline
\end{tabular}

** indicates rejection of the null at the $5 \%$ significance level.

${ }^{20}$ Ball (1997) also adopts the methodology of Granger-causality testing. For most European countries he found that GDP was affected by housing investment, and that "housing systems in the long run [were] strongly influenced by the general ... performance of the economy." This, latter point, may suggest causality in two directions. 
The next step was then to test for Granger causality. Table A3 presents the results for pairwise Granger causality tests. Ten lags of data were used in the test to permit ample time for feedbacks between the variables to be picked-up.

Table A3 Granger-Causality Test Results

\begin{tabular}{|c|c|c|}
\hline Null Hypothesis & F Statistic & Probability \\
\hline House Prices Do Not Granger-Cause GDP & 2.112 & 0.031 \\
\hline GDP Does Not Granger-Cause House Prices & 1.034 & 0.422 \\
\hline No. of Observations $=114$ & & \\
\hline
\end{tabular}

The results suggest that it is possible to reject the null hypothesis that house prices do not Grangercause GDP. However we cannot reject the null that GDP does not Granger-cause house prices. Hence, Granger-causality runs in one direction only, from house prices to GDP. This result also holds when examining changes in the value of these variables.

\section{References}

Ball, M. and M. Grilli, "Housing Markets and Economic Convergence in The European Union." The Royal Institute of Chartered Surveyors, London, 1997.

Granger, C.W.J. "Investigating Causal Relations by Econometric Models and Cross-Spectral Methods." Econometrica, 37, 1969, 424-438.

Johansen, S. "Likelihood-based Inference in Cointegration Vectors in Gaussian Vector Autoregressive Models." Econometrica, 1991, 59, 1551-1580. 